\title{
Mecanismos de ficción autobiográfica en Vivir para contarla de Gabriel García Márquez
}

Preparado por: Dra. Saadeya Mousa Abd El Azeem

Profesora en El Departamento de Español Facultad de Al-Alsun - Universidad de Kafr El Sheikh 


\section{ملخص بحث: آليات سرد السيرة الأتية في رواية "يحكيها من عاشها" \\ لجابرييل جارثيا ماركيز.}

يلقي هذا البحث الضوء على آليات سرد السيرة الذاتية عند الكاتب جابرييل جارثيا ماركيز (1927 كولومبيا - 2014 المكسيك).

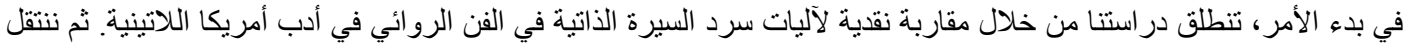

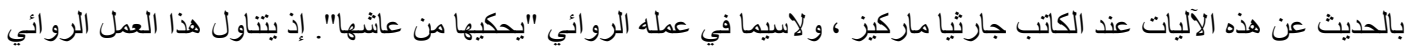

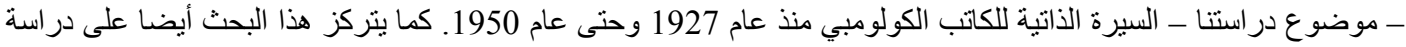

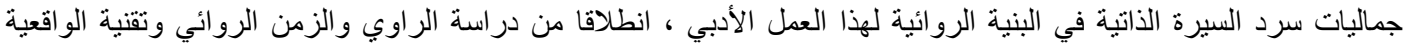

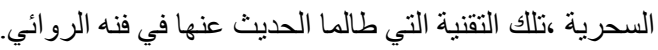

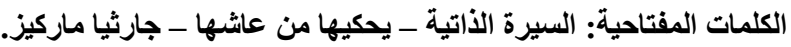

Abstract: Autobiographical mechanisms in "Living to Tell the Tale" of Gabriel García Márquez.

This research sheds light on the autobiography Mechanisms of the writer Gabriel García Márquez (1927 Colombia - 2014 Mexico). Our study begins with a critical approach to the mechanisms of biographical narration in fiction art in Latin American literature. Then we turn to talking about these mechanisms when the author Garcia Marquez, especially in his novel "Living to Tell the Tale". This fictional work - the subject of our study - deals with the biography of the Colombian writer from 1927 until 1950. The research also focuses on studying the aesthetics of recounting the biography in the fictional structure of this literary work, starting from the study of the narrator and the novel and the technique of magic realism, the technique that has been talked about in his narrative art.

Key Words: Autobiography - Living to Tell the Tale - García Márquez.

\section{Mecanismos de ficción autobiográfica en Vivir para contarla de Gabriel García Márquez. Preparado por: Dra. Saadeya Mousa Abd El Azeem Profesora en El Departamento de Español Facultad de Al-Alsun - Universidad de Kafr El Sheikh Email: $\underline{\text { Saadeya.mousa_2011@yahoo.com }}$}

\section{Resumen}

El propósito de este trabajo consiste en hacer una aproximación a la ficción autobiográfica que ofrece la narrativa del escritor colombiano Gabriel García Márquez, sobre todo en su novela Vivir para contarla (2002).

La elección del tema se debe a la actualidad y la importancia que adquieren los estudios críticos sobre la autobiogrfía, las memorias y las escrituras del Yo en el campo de la narrativa hispanoamericana, sobre todo en la creación novelística de García Márquez. En Vivir para contarla, el primer libro de sus memorias, el escritor colombiano vincula el desarrollo de su vocación artística y las vivencias que han rodeado su universo literario con los acontecimientos ocurridos en la historia colombiana. 
Este trabajo arroja la luz sobre la ficción autobiográfica, sobre todo en su libro de memoria Vivir para contarla. Por eso, partimos primero de un estudio crítico de los mecanismos de la escritura autobiográfica o las escrituras del «Yo», sobre todo en las letras hispanoamericanas. Luego, hacemos una Breve aproximación a la ficción autobiográfica en el libro de memoria Vivir para Contarla de García Márquez, en el que el escritor colombiano intenta unir los hilos proyectados con sus recuerdos, formando una especie de autobiografía novelizada, que depende de la dramatización de sus propias experiencias vitales que a su vez fascinan y atraen la atención del lector.

En segundo término, este trabajo se propone discutir los mecanismos del discurso narrativo autobiográfico en Vivir para contarla. El fundamento genérico que nos permite analizar este libro de memoria - Vivir para contarla -, exige un delineamiento de los mecanismos de narración autobiográfica, partiendo de un estudio estético del punto de vista narrativo, la dimensión temporal, y la técnica del Realismo mágico.

A continuación, vamos a determinar en puntos los principales objetivos e hipótesis de nuestro trabajo investigativo:

- Identificar reflexiones sobre la escritura autobiográfica.

- Realizar un estudio analítico sobre la ficción autobiográfica en la novela Vivir para contarla de García Márquez.

- Llevar a cabo un análisis estético de los mecanismos de ficción autobiográfica del corpus establecido, arrojando la luz sobre el punto de vista narrativo, la dimensión temporal y la técnica del realismo mágico en el discurso narrativo de la novela objeto de estudio.

Palabras clave: Autobiografía - Vivir para contarla - García Márquez. 


\section{Introducción}

Gabriel García Márquez (Colombia,1927- México, 2014) - conocido como Gabo - es un periodista, escritor, guionista y editor colombiano. Es el máximo exponente del realismo mágico y uno de los autores más famosos, no sólo en Hispanoamérica, sino en todo el mundo, sobre todo con la autoría de su novela Cien años de soledad (1967), obra cumbre del llamado realismo mágico, y de que obtuvo el premio Nobel de Literatura en 1982. Por eso, García Márquez sitúa la narrativa hispanoamericana en la primera línea de la literatura mundial con la publicación de esta novela.

García Márquez inició estudios de Derecho en La Universidad Nacional de Colombia, pero no culminó su carrera de abogado por las malas condiciones de su país, por eso se dedicó al periodismo. Vivió la mayor parte de su vida en México. $\mathrm{Su}$ interés por las tertulias culturales y literarias sobre todo, el grupo de Barranquilla ${ }^{1}$ - le permitió leer a las eminentes figuras realistas anglosajones, como es el caso de; Ernest Hemingway, Virginia Wolf, James Joyce, Wiliam Faulkner, lo cual influyó ideológicamente sobre su formación cultural y literaria.

$\mathrm{Su}$ obra narrativa se compone de novelas, cuentos, reportajes periodísticos, memorias, guiones televisivos, drama, y reportajes novelados. Sus novelas más conocidas son; Cien años de soledad (1967), Crónica de una muerte anunciada (1981), El amor en el tiempo de la cólera (1985), y Vivir para contarla (memorias, 2002).

García Márquez se premió por varias instituciones, ganando numerosos premios que celebraban su pensamiento y su obra, entre los que destacaron; Premio Nobel de Literatura (1982), Premio Rómulo Gallegos (1972), y Condecoración Águila de Azteca de México (1982). La mayoría de sus novelas han sido vinculadas a la ficción fílmica y televisiva, y han trasladado a varios idiomas.

\section{Reflexiones sobre la escritura autobiográfica o las escrituras del «Yo».}

La autobiografía o las escrituras del $Y o$ en las letras hispanoamericanas es un discurso narrativo destacable, que vive una época fecunda de creación y difusión, generando una considerable posición literaria y crítica, con diversas clases de lectores. En efecto, las escrituras del Yo se destacan por su capacidad de representar seres, que cuentan con una resonancia pública para el lector. Como

\footnotetext{
1 - Barranquilla: es una tertulia literaria que se formó entre 1940 y 1950 en Colombia. Sus fundadores son García Márquez y Cepeda Samudio. Se dedican fundamentalmente en el campo del periodismo, y se establecen un diálogo cotidiano e interdisciplinario en sus escritos ensayísticos y periodísticos. Véase: Jacques Gilard, "El grupo de Barranquilla y la renovación del cuento colombiano"(1983) en Saól Sosnowski (ed.), Lectura crítica de la literatura americana: actualidades fundacionales, Caracas: Fundación Biblioteca Ayacucho,1996, p. 36.
} 
resultado, se produce una especie de autoevaluación, es que la vida de este ente se convierte en una materia de interés colectivo ${ }^{2}$. Por otra parte, el lector tiene curiosidad de saber la trayectoria vital de esta persona, de identificarse con ella, o de experimentar o aprovechar de su experiencia en la vida. En este sentido, la investigación autobiográfico-narrativa en Hispanoamérica cuenta con una identidad propia dentro de los estudios críticos que vale la pena considerar, ya que permite representar y componer dimensiones relevantes de la experiencia del ser autobiografiado.

En las escrituras autobiográficas, se interfieren y se asemejan la vida narrada y la experiencia vivida del autor, creando una ficción narrativa autobiográfica, es que el autor pueda presentar tanto su experiencia personal y como su deseo de vivir otras vidas. Vargas Llosa en su libro «La verdad de las mentiras» dice que: “. [...] las novelas no hacen más que mentir y que, mintiendo, expresan una curiosa verdad que sólo se enuncia ocultada por aquello que no es ${ }^{* 3}$. Lo mismo se afirma por el poeta Octavio Paz en su ensayo titulado «La pregunta de Carlos Fuentes»: “Quizá la creencia en la identidad personal es un recurso de nuestra nadería para dar un poco de verosimilitud a nuestro descosido y discontinuo transcurrir ${ }^{* 4}$. Y continúa diciendo: "La memoria es nuestro bastón de ciego en los corredores y pasillos del tiempo. No nos devuelve esa pluralidad de perosnas que hemos sido pero abre ventanas para que veamos -no tanto a la intocable realidad como a su imagen ${ }^{.5}$.

Como resultado, se puede estimar el $Y o$ autobiografiado como un ente ficcional, sujeto tanto a vida narrada como vivida, es que la recuperación memorística requiere imaginación, selección y fabulación de los diversos hechos ocurridos en el pasado, y que de alguna manera contribuye a componer nuestra identidad en el presente. Así como, “....] esta tarea se dinamiza en la intricada relación que el yo mantiene con el otro, y es la cuestión de la alteridad, por fuerza, el parámetro que dirige el rescate de aquellas personas que fuimos en la sucesión temporal y que se condensan en las imágenes que nosotros y los otros hacemos en el presente ${ }^{* 6}$. Por lo que, las escrituras autobiográficas teóricamente son el resultado de la necesidad de conferir verosimilitud a la existencia, y se somete a

\footnotetext{
2 - Véase: Heliosa Costa Miltón: Voces en torno al "YO”: (Auto) biografías de Gabriel García Márquez, Actas XVI Congreso AIH, Universidade Estadual Paulista-UNESP, São Paulo, p. 1.

3 - Mario Vargas Llosa, La verdad de las mentiras, (Reseña), Lima. Ediciones PEISA,1996, P.7.

4- Octavio Paz, «La pregunta de Carlos Fuentes», en In/mediaciones, Barcelona, Seix Barral, 1981, Barcelona, Seix Barral, 1981. p. 175.

5 - Ídem.

6 - Heliosa Costa Miltón: Voces en torno al "YO”: (Auto) biografías de Gabriel García Márquez, op. cit., p. 2.
} 
múltiples contextos socio-históricos, que a su vez, influyen de una manera u otra en su discurso narrativo.

En el caso de la literatura hispanoamericana, anotamos que una parte considerable se elabora en las escrituras del $Y o$ con fines políticos y sociales, empezando por las «Crónicas de las Indias», y los testimonios idealistas, pasando por los escritos nacionales del periodo de independencia y las producciones literarias contemporáneas. Así que, la autobiografía en Hispanoamérica es *....] un ejercicio de memoria que a la vez es una conmemoración ritual, donde las reliquias individuales (en el sentido que les da Benjamín) se secularizan y se representan como sucesos compartidos ${ }^{\cdot 7}$, y se interfiere la voz individual del autor que redacta su autobtografía con la voz colectiva de su entorno circundante. De modo que este peculiar condición se debe en parte al "acoso creciente a que están siendo sometidos conceptos como historia, poder, sujeto, esencia, representación, referencialidad o expresividad"8. Y por consiguiente, la narración autobiográfica ofrece un marco conceptual y metodológico conveniente, ya que cuenta con sus propias líneas y reflexiones de desarrollo en los estudios críticos en un intento de analizar y criticar aspectos esenciales del desarrollo humano.

\section{Breve aproximación a la ficción autobiográfica en la narrativa de García Márquez (Vivir para Contarla: Un ejemplo especial).}

La obra narrativa de García Márquez se enmarca fundamentalmente en el movimiento literario denominado El realismo mágico, - hablamos detalladamente de esta técnica más adelante - en el que se interfiere lo mítico o fantástico con los hechos reales del relato. El autor colombiano formula así su concepción precisa de la relación entre lo maravilloso y la realidad americana, reclamando la voluntad del escritor de representar lo real como mágico. Y aquí me inspiro en sus propias palabras "Yo creo que particularmente en Cien años de soledad yo soy un escritor realista porque creo que en América Latina todo es posible, todo es real. Es un problema técnico en la medida en que el escritor tiene dificultad en transcribir los acontecimientos que son reales en América Latina porque en un libro no se creerían. Vivimos rodeados de cosas extraordinarias y fant_asticas y los escritores ${ }^{.9}$. De modo que, su obra creativa atrae y fascina al lector.

7- Sylvia Molloy (1996), La escritura autobiográfica en Hispanoamérica, Acto de presencia, México: El Colegio de México : Fondo de Cultura Económica (FCE), p. 20.

8- Loureiro, Ángel G. (1991): Problemas teóricos de la autobiografía, Anthropos: Boletín de información y documentación, ISSN 0211-5611, № Extra 29, 1991 (Ejemplar dedicado a: La autobiografía y sus problemas teóricos. Estudios e investigación documental), p. 6.

9 - Mario Vargas Llosa (1971), García Márquez. Historia de un suicidio, Barcelona: Barral. pp. 183 $-184$. 
Márquez ha afirmado en diversas ocasiones que la literatura es una especie de hipnosis a la que somete al lector. William Ospina refiere la siguiente anécdota; "Recuerdo que un día le dije: «Gabo: tú eres ya un autor más leído que el Espíritu Santo, y eso es pecado. ¿Podrías contarme tu secreto?». Me contestó con una sonrisa: «Te lo voy a revelar. Todo consiste en evitar que el lector se despierte ${ }^{* 10}$. De tal modo, el proyecto literario de Márquez siempre aborda los relatos de infancia de su abuela con sus intereses y preocupaciones políticos en Hispanoamérica, abriendo el camino hacia la aparición de la denominada obra autobiográfica o de memoria, en la que se narra las penurias y las dificultades del escritor colombiano en los primeros treinta años de su vida.

Evidentemente, García Márquez es una de las eminentes figuras que cultivan su propia autobiografía, sobre todo en su libro Vivir para contarla. El tono autobiográfico en la creación narrativa de García Márquez es una característica destacable. Tal técnica apareció en 1994 con la publicación de su novela "Del amor y otros demonios", cuyos elementos discursivos se operan en la intersección de la voz del autor en el prólogo del relato, - donde el autor recupera el inicio de su carrera periodística y su infancia - con la voz del narrador.

Lo mismo apareció en su novela El general en su laberinto, publicada en 1989, es que el escritor colombiano explica las fases de su proceso creador, ofreciendo diversas facetas de su experiencia vital y literaria.

En estas dos novelas mencionadas arriba, García Márquez sintetiza múltiples formulaciones que enlazan el $Y o$ autobiográfico con el pensamiento intelectual y crítico sobre Hispanoamérica. Puesto que, Vivir para contarla representa la plena ejecución del yo personal de su autor. En palabras de Juan Gustavo; "Cómo escribir memorias después de semejantes novelas. Cuando sus personajes, con toda la carga autobiográfica que puedan acarrear, se han vuelto seres de entre casa y parte de su propia familia para lectores del mundo entero ${ }^{\cdot 11}$.

Vivir para contarla (2002) es un libro enciclopédico memorístico, que se engloba dentro de las categorías de libros de autobiografía o de memoria de García M-árquez, que sintetiza su proceso creador, su trayectoria vital y literaria, además de abarcar diversas facetas de la historia y la cultura hispanoamericana. Tambié es

\footnotetext{
10 - William Ospina. García Márquez y el poder de la poesía. (2007): Artículo de la revista digital Número. www.revistanúmero.com. Edición 52. Marzo - mayo de 2007. Fecha de la visita de la revista web: 20/12/2018, 8:00 PM.

11 - Juan Gustavo Cobo Borda (2002): Vivir para contarla, de Gabriel García Márquez. El filón del joyero. 31 de diciembre de 2002, Letras Libres, https://www.letraslibres.com/mexico/vivir-contarlagabriel-garcia-marquez. Fecha de visita de la página web: 26 / 01/ 2019 - 8:30 PM.
} 
una obra autobiográfica novelada que se destaca por la subjetividad de su autor, transmitiendo un saber histórico de manera literaria.

Paralelamente, Vivir para contarla es un libro de memoria que, representa una laberíntica explicación, por parte de su escritor, creando un paralelismo entre su producción estética y periodística; y entre la literatura y la historia en Hispanoamérica. En efecto, Vivir para contarla "[...] es una obra que se corresponde con esa faceta testimonial de su escritura de la cual no sólo son muestra los gruesos volúmenes en los que se recopilan sus artículos periodísticos sino también obras como Relato de un náufrago o Noticia de un secuestro "12, convirtiéndose en una galería conmovedora de complejos e inolvidables seres humanos, en cuyo seno surgió un ser excepcional, es decir, un escritor, pretendiendo mostrar una experiencia vivida de los sucesos históricos y personales.

El epígrafe de Vivir para contarla se caracteriza por el hibridismo, es que interfieren los discursos referenciales e imaginativos. El propio García Márquez nos informa en el epígrafe de esta obra: "La vida no es la que uno vivió, sino la que recuerda y como recuerda para contarla ${ }^{\cdots 13}$. Él intenta, a nuestro juicio, unir los hilos proyectados con sus recuerdos, formando una especie de autobiografía novelizada, que depende de la dramatización de sus propias experiencias vitales que a su vez fascinan y atraen la atención del lector.

Este libro de memorias - Vivir para contarla - se divide en dos partes principales. En la primera parte, García Márquez nos presenta las distintas facetas de su vida infantil, intentando acercarnos a sus orígenes. El relato arroja la luz sobre aspectos definitorios como su pueblo natal Aracataca, la casa de sus abuelos, la figura tradicional de sus abuelos, y su mundo infantil repleto de fantasías, la figura miserable de sus padres y la pobreza agotadora en la que vivían. En palabras de Gabo; "La pobreza de mis padres en Barranquilla era agotadora, pero me permitió la fortuna de hacer una relación excepcional con mi madre. Sentía por ella, más que el amor filial comprensible, una admiración pasmosa por su carácter de leona callada pero feroz frente a la adversidad, y por su relación con Dios, que

12 - Julio Hans Casado Jensen, Vivir para contarla como trabajo mnemónico individual y colectivo, 1/1/2006, Universidad de Copenhague, Literaturas coloniales y postcoloniales, Artículo publicado en:

https://www.researchgate.net/publication/277182067_Vivir_para_contarla_como_trabajo_mnemoni co individual_y colectivo, Fecha de visita de la página web: 20/02/2019, 9: 30 PM.

13 - Gabriel García Márquez (2002): Vivir para contarla, Editorial Sudamérica. 1ª . ed. Buenos Aires, Introducción de la novela, p. 1. 
no parecía de sumisión sino de combate. Dos virtudes ejemplares que le infundieron en la vida una confianza que nunca le falló ${ }^{114}$.

Curiosamente, Vivir para contarla cuenta la historia de la vida de García Márquez entre 1927 y 1950, acabando con la propuesta de matrimonio a su esposa. Su temática gira sobre todo en torno a la familia, la escuela y los primeros años como periodista y escritor de cuentos, refiriendo a numerosos hechos de su vida real desde sus bisabuelos guajiros hasta su viaje a Europa como corresponsal del diario El Espectador, citando de personajes aparecidos en sus otras novelas; incluyendo la masacre de las Bananeras que aparece en Cien años de soledad y aquellos amigos cuya vida y muerte sirvieron de modelos para Crónica de una muerte anunciada, y cómo la historia de sus padres sirvió de inspiración para El amor en los tiempos de cólera ${ }^{15}$.

A García Márquez le concede un enorme interés a los minuciosos detalles de su vida en su narración, regulando este horizonte rememorativo, en cuanto a la venta de la casa de la infancia y la gravedad moral de un duelo de honor, donde su abuelo mata a un copartidario de las guerras civiles; aquella figura femenina arquetípica y excepcional de su madre, su infancia con sus miedos de niño, sus pesadillas, "(...) los gritos de adolescente interno de Zipaquirá. (...) Tener que cumplir con el sueño trunco del progenitor, un título profesional, siendo el hijo mayor de once hermanos donde no siempre se cumplían las tres comidas diarias, sugiere ya la tensión eléctrica que sacude todo el libro en sus nudos conflictivos ${ }^{* 16}$. Así que el primer capítulo es un prólogo de esa escena primordial, es decir; "un joven lee luz de agosto de Wiliam Faulkner mientras acompaña a su madre a vender la casa de los abuelos en Aracataca y Posterga, una vez más, sus estudios convencionales, sabedor intuitivo de que ni colegios ni universidades, ni títulos ni certificados, le otrorgarán licencia de escritor ${ }^{* 17}$. Así que, sus memorias de infancia y juventud se consideran el archivo, en el que se fundaría el imaginario que, con el traspaso de los años, daría lugar a algunas de sus creaciones narrativas en la literatura hispanoamericana.

Sin embargo, en la segunda parte de las memorias, que la crítica califica como menos lograda e interesante de todo el libro, el autor nos relata su trayectoria

\footnotetext{
14 - Ibíd. p. 171.

15 - Justo Fernández López, García Márquez Gabriel, Artículo sacado de: Historia de la literatura hispanoamericana, www.hispanoteca.eu, Fecha de la visita de la página web: 01 / 02 / 2019.

16 - Juan Gustavo Cobo Borda (2002): Vivir para contarla, de Gabriel García Márquez. op. cit,.

Fecha de visita de la página web: 26 / 01/ 2019 - 8:30 PM.

17 - Véase: Gabriel García Márquez (2002): Vivir para contarla, op. cit., p. 5.
} 
profesional como periodista. Pretende explicar su incorporación al mundo periodístico. Cuenta los problemas y los obstáculos sorteados con el fin de llegar a ser un escritor y periodista famoso. En esta parte, Márquez intenta crear un espacio autobiográfico en el cual se puede hacer una relectura de sus otras obras de ficción.

Por lo que, Vivir para contarla es un palimpsesto de las obras narrativas de García Márquez, es que el discurso descriptivo de este libro nos ayuda a descubrir historias que se participen de un modo u otro en la escritura de otras obras; tal es el caso de: Cien años de soledad, El amor en tiempos de cólera, El coronel no tiene quien le escriba y Crónica de una muerte anunciada. En palabras de la ensayista Martha Michell García Garduño: "Vivir para contarla es una guía de la búsqueda del propio Márquez, en el ámbito de la creación artística, el tarbajo, reflexiones y recuerdos que avanzan y retroceden en el tiempo" ${ }^{* 18}$. Además, es una guía de lectura para toda su obra, ilustrando paisajes inolvidables en la trayectoria del autor colombiano.

\section{Mecanismos del discurso narrativo autobiográfico en Vivir para contarla.}

El fundamento genérico que nos permite analizar este libro de memoria Vivir para contarla -, exige un delineamiento de los mecanismos de narración autobiográfica, partiendo de un estudio estético del punto de vista narrativo, la dimensión temporal, y la técnica del Realismo mágico.

\section{- El punto de vista narrativo en Vivir para contarla.}

El punto de vista narrativo - según Genette ${ }^{19}$ - es la representación narrativa en la que se expresan las relaciones entre narración y discurso. En Vivir para contarla, el punto de vista - según Genette - está presentado por un narrador intradiegético, es que un personaje del discurso es quien narra - El propio Gracía Márquez -, utilizando la primera persona.

En cuanto a la voz narrativa en Vivir para contarla, que intenta reconocer el grado de subjetividad de la narración, - según la clasificación de Genette - es autodiegético, donde el narrador cuenta sus propias experiencias, y actúa como un personaje central del relato.

El narrador de este libro de memoria busca una cosmovisión de la realidad histórica. Se encuentra inmerso en una textura memorística compleja que expone una visión interpretada y lógica del pasado. Aúnque la autoría de esta obra narrativa se remonta al año 2002, García Márquez nos traslada a tiempos pasados

18. Martha Michell García Garduño, Ensayo del libro "Vivir para contarla", https.//www.monografías.com/docs/ensayo-del-libro-vivir-para-contarla, 19 de mayo de 2013, Fecha de la visita de la página web, 30 / 01/2019.

19 - Véase: Gerard Genette (1972): Discurso del relato, Barcelona, En: Figuras III.: Lumen., Esp. Introducción, pp. $71-76$. 
narrados en presente, como si pertenecieran al momento de la narración. Nos relata una serie ininterrupmida de recuerdos, que a su vez, evocan ambigüedad notable en los sucesos narrados, de modo que el tono autobiográfico coincide con el narrador y el protagonista.

Anotemos que este libro de memoria se ve presentando una narración abierta infinita, de modo que cada memoria o recuerdo está en estrecha relación con otra en una serie inacabable. Puesto que, hay una coincidencia considerable en la figura del autor / narrador / personaje, y se desliza en una serie anecdótica infinita, ya que la identidad personal del propio Márquez surge de las narraciones que él cuenta sobre sí mismo.

Ahora bien, la imagen del autor aparecida en Vivir para contarla es ajena de toda subjetividad, es que el escritor aparece en los hechos del relato como un recopilador y transmisor de memorias propias e impropias, ligadas a su patrimonio cultural y ancestral de sus antepasados, lo cual indica la técnica narrativa autobiográfica.

\section{- La dimensión temporal en el discurso narrativo de Vivir para Contarla.}

García Márquez, en su novela, - según Genette ${ }^{20}$ - adopta dos recursos de tiempo extratextual en la narración. Así, el tiempo narrativo extratextual es la época en qué se sitúan las acciones del relato, en relación con el tiempo presente del autor; es decir, ambientación temporal histórica y ambientación temporal contemporánea. Esta primera técnica usada muestra que la acción se desarrolla en una época muy alejada del presente del autor, es que Márquez nos cuenta sus memorias infantiles y adolescentes y algunos hechos del archivo histórico de su patria de 1927 a 1950, que se sitúan en un punto muy alejado del tiempo de la autoría de la novela en 2002. Al mismo tiempo, el escritor utiliza la ambientación temporal contemporánea, donde hay otros sucesos en el relato que se narran en la actualidad del autor, tal es el caso de su trabajo como periodista y escritor de una inmensa producción literaria.

Ahora bien, la organización del tiempo interno o textual en esta novela es discontinuo, donde la acción se narra siguiendo una cadena temporal no líneal, incluyendo saltos cronológicos. El narrador depende de la técnica retrospectiva analepsis $^{21}$ - o el Flashback - otra técnica narrativa autobiográfica -, donde él interrumpe la acción y retrocede en el tiempo, presentando acciones ya pasadas, exhibiendo una hibridez memorística contrastada.

\footnotetext{
20 - Véase: Ibíd. pp. 92 - 94.

21 - Ídem.
} 
Entre los diversos modos de memoria aparecidos en este libro, cuyo discurso depende de la técnica del Flashback, mencionamos por ejemplo: Recuerdos del contraste entre una memoria infantil y de adolescencia en unas decisiones vitales del propio Márquez, Memoria transmitida por otros; por ejemplo, las historias contadas por su abuelo: 'Yo conocía el episodio como si lo hubiera vivido, después de haberlo oído contado y mil veces repetido por mi abuelo desde que tuve memoria ${ }^{\cdot 22}$, Memoria propia en contraposición con las de otros, Memoria colectiva que invade el yo personal del autor tal es esl caso de la matanza de las bananeras, Memoria individual que invade la colectiva, como es el caso del senador que pidió un minuto de silencio en memoria de los tres mil mártires de la matanza de las bananeras, es que Márquez menciona este código en su novela Cien años de soledad para mostrar la crueldad de la matanza, y otros falsos recuerdos inventados por la imaginación del escritor, como el legendario cantor de Vallenatos que derrotó al mismo Demonio.

\section{- El Realismo Mágico en la ficción narrativa de Vivir para contarla.}

Otra técnica utilizada en Vivir para contarla, es el realismo mágico, que es una característica constante en la narrativa garcíamarquiana, como hemos señalado de antemano. Su técnica consiste en narrar una historia "a través de la visión del mundo de los propios personajes, sin indicación alguna por parte del autor de que se trate de una visión pintoresca, folclórica o supersticiosa. El mundo es como los personajes creen que es ${ }^{-23}$. En dicha técnica, se funde lo mítico y lo imaginario con los hechos reales del relato. El propio Gabo nos informa: "pienso que la imaginación es una facultad especial que tienen los artistas para crear una realidad nueva a partir de la realidad en que viven. Que, por lo demás, es la única creación artística que me parece válida. Hablemos, pues, de «la imaginación en la creación artística en América Latina» y dejemos la fantasía para uso exclusivo de los malos gobiernos $^{\cdot 24}$.

En el caso de nuestro libro de memoria, aquel mundo mágico y sobrenatural se transmite mediante las imágenes femeninas - su abuela y su madre - de su infancia en Aracataca. Desde su niñez, Márquez está envuelto en una especie de atmósfera mágica, donde lo absurdo y lo increíble ocurren diariamente. Él dice; "Mi infancia transcurrió en una casa grande, muy triste, con una hermana que comía tierra y una abuela que adivinaba el porvenir, y numerosos parientes de

22 - Gabriel García Márquez (2002): Vivir para contarla, op. cit., p. 22.

23 - Gerald Martin (2009): Gabriel García Márquez, una vida. (Libro), Editorial Random House Mondadori. Barcelona, España, P.315.

24 - Gabriel García Márquez (1997): Fantasía y creación artística. Publicado en Notas de prensa 1980-1984. Editorial Norma. Bogotá, Colombia. Mayo de 1997. P. 149. 
nombres iguales que nunca hicieron mucha distinción entre la felicidad y la demencia ${ }^{\cdot 25}$. Además, Gabo comparte con su abuela “una especie de código secreto mediante el cual nos comunicábamos con un universo inivisible ${ }^{* 26}$, que a su vez, de día le encanta y de noche le causa temor.

El realismo mágico aparece retratado obviamente en la divertida anécdota del loro Lorenzo el Magnífico y el toro escapado de la corrida. Y aquí me inspiro en esta larga acotación de Vivir para contarla:

“Era el reino de las mujeres que vivían o servían en la casa, y cantaban a coro con la abuela mientras la ayudaban en sus trabajos múltiples. Otra voz era la de Lorenzo el Magnífico, el loro de cien años heredado de los bisabuelos, que gritaba consignas contra España y cantaba canciones de la guerra de Independencia. [..]. Un 20 de julio, a las tres de la tarde, alborotó la casa con chillidos de pánico:

- ;El toro, el toro! ;Ya viene el toro!

En la casa no estaban sino las mujeres, pues los hombres se habían ido a la corraleja de la fiesta patria, y pensaron que los gritos del loro no eran más que un delirio de su demencia senil. Las mujeres de la casa, que sabían hablar con él, sólo entendieron lo que gritaba cuando un toro cimarrón escapado de los toriles de la plaza irrumpió en la cocina con bramidos de buque y embistiendo a ciegas los muebles de la panadería y las ollas de los fogones. Yo iba en sentido contrario del ventarrón de mujeres despavoridas que me levantaron en vilo y me encerraron con ellas en el cuarto de la despensa. Los bramidos del toro perdido en la cocina y los trancos de sus pezuñas en el cemento del corredor estremecían la casa. De pronto se asomó por una claraboya de ventilación y el resoplido de fuego de su aliento y sus grandes ojos inyectados me helaron la sangre. Cuando los picadores lograron llevárselo al toril, ya había empezado en la casa la parranda del drama, que se prolongó por más de una semana con ollas interminables de café y pudines de boda para acompañar el relato mil veces repetido y cada vez más heroico de las sobrevivientes alborotadas. ${ }^{\prime 27}$.

A nuestro modo de ver, de esta larga acotación, nos concluimos que la narración de Gacría Márquez es resultado de la comprensión del archivo o del registro histórico de su país natal, pues construye relación entre el pasado colonial y las guerras de independencia y liberación mediante el uso de símbolos míticos, lo cual afirma la técnica del realismo mágico. Así que, el loro centenario representa la conmemoración del levantamiento de los colombianos contra España celebrada el 20 de julio. Sin embargo, el toro representa España en su época más remota y retrasada y la coexistencia de esta tradición cultural a pesar de la conquista y las guerras, es que los toros y las corridas de toros son el resto de un culto religioso muy antiguo.

25 - Plinio Apuleyo Mendoza y Gabriel García Márquez: (2004): El olor de la guayaba. Grupo Editorial Random House Mondadori. Madrid, España, p. 81.

26 - Gabriel García Márquez (2002): Vivir para contarla, op. cit., P. 96.

27 - Ibíd. p. 48. 
Otro ejemplo que demuestra este mundo mítico, lleno de mitologías es la creencia en la región de la Sierpe, cuya descripción nos transmite a los reinos fabulosos. En palabras del propio García Márquez: "Un país de leyenda dentro de los límites de Sucre al que sólo podía llegarse por tremedales humeantes, donde uno de los episodios más corrientes era vengar una ofensa con un maleficio como aquel de una criatura del demonio dentro del vientre" 28 .

En efecto, la realidad retratada en el discurso narrativo de Vivir para contarla está sujeta a un círculo mágico infinito. Para García Márquez, La multiculturalidad de Colombia es una característica constante, que se ve influida por el racionalismo europeo proveniente de la colonización española a los países de Hispanoamérica. Y aquí me inspiro en sus propias palabras: "En Latinoamérica terminamos por ser un laboratorio de ilusiones fallidas. Nuestra mayor virtud es la creatividad y, sin embargo, no hemos hecho mucho más que vivir de doctrinas recalentadas y guerras ajenas, herederos de un Cristóbal Colón desventurado que nos encontró por casualidad cuando andaba buscando las Indias ${ }^{-29}$. Efectivamente, el escritor colombiano nos ofrece una cosmovisión tan completa y tan arraigada en las raíces de la humanidad, retratando el colorido de la vida colombiana.

\section{CONCLUSIÓN}

Vivir para contarla es una autobiografía, que resulta de la evaluación que hace el yo personal de García Márquez, en la que su vida se convierte en una materia de interés colectivo. En este libro de memoria, se interfieren y se unen la vida narrada y la experiencia vivida de su escritor, creando una considerable ficción narrativa autobiográfica. Puesto que, se estima el yo autobiografiado de García Márquez como un ente ficcional, de modo que su recuperación memorística evoca imaginación, descripción y relato de los distintos hechos de su pasado, y que en su totalidad contribuye a formar su yo personal en el presente como un escritor mundial, intentando conferir verosimilitud a su existencia.

El escritor colombiano sintetiza múltiples formulaciones, pues sus memorias de infancia y juventud - en la primera parte de su libro de memoria - se consideran el archivo, en el que se fundaría el imaginario, que a su vez daría lugar a su eminente creación narrativa. Mientras que la segunda parte que la crítica le considera menos lograda, Márquez nos relata su trayectoria profesional como periodista y escritor, creando un espacio narrativo autobiográfico del que se puede hacer una relectura de sus otras obras narrativas.

\footnotetext{
28 - Gabriel García Márquez (2002): Vivir para contarla, op. cit., P. 417.

29 - Gerald Martin. Gabriel García Márquez, una vida, op. cit., p. 593.
} 
En Vivir para contarla aparecen obviamente los mecanismos de ficción narrativa autobiográfica. El punto de vista narrativo está presentado por un narrador intradiegético-autodiegético, porque Márquez es quien narra los sucesos en la primera persona, relatando sus propias experiencias, y actúando como un monitor en torno al cual giran todos los personajes y los hechos de la novela.

En efecto, García Márquez nos presenta una imagen autobiográfica objetiva, actúando como un recopilador y transmisor de memorias propias e impropias en íntima relación con su patrimonio cultural e histórico.

La dimensión temporal es otra característica destacable en la narración autobiográfica de Vivir para contarla, porque García Márquez usa la ambientación temporal histórica y contemporánea a la vez. Él nos cuenta sus memorias y algunos hechos del archivo histórico de su país de 1927 a 1950, que se sitúan en un punto muy alejado de la autoría de su obra en 2002. Al mismo tiempo, nos cuenta sucesos y escenas contemporáneas de su vida actual, como su trabajo en el mundo del periodismo y la escritura de los libros.

La técnica retrospectiva o El Flashback es otro mecanismo autobiografiado utilizado en Vivir para contarla, donde Márquez oferce una hibridez memorística del archivo de sus recuerdos.

El realismo mágico es otro rasgo definitorio de los mecanismos de narración autobiográfica, en el que se funde lo imaginario con lo real. En este libro de memoria se funden aquel universo mágico y sobrenatural representado por las figuras femeninas de la infancia de Gabo en su pueblo Aracataca, con los acontecimientos del registro histórico, construyendo una relación multicultural entre el pasado colonial y las guerras de independencia de - Colombia - su país natal.

Entonces, Vivir para contarla es un libro de memoria sometido a contextos socio-históricos, cuya trama no representa sólo la autobiografía de su autor, sino también expone la hibridez histórica, étnica y cultural de las sociedades postcoloniales y se inscribe en la tradición occidental. García Márquez no exhibe sólo su propia autobiografía, sino también nos cuenta la historia de su patría en una sinfonia musical, en la que lo mítico se mezcla con lo real, la voz individual se funde en la voz colectiva y la identidad personal se mezcla con la identidad nacional.

Por último, se puede decir que Vivir para contarla es un archivo memorístico tanto para García Márquez como para su patría, donde se reúnen obviamente los mecanismos de ficción narrativa autobiográfica garcíamarquiana. 


\section{BIBLIOGRAFÍA}

- Cobo Borda, Juan Gustavo.

- (1992): Gabriel García Márquez. Testimonios sobre su vida. Ensayos sobre su obra. Editores, Siglo del hombre editores. Bogotá. Colombia.

- (2007): El arte de leer a García Márquez. Texto: Cien años de soledad y la cándida Eréndira. Juan Bosch. Editorial Belacqva. Serie Documentos. Barcelona, España.

- Costa Miltón, Heliosa. Voces en torno al "YO": (Auto)biografías de Gabriel García Márquez, Actas XVI Congreso AIH, Universidade Estadual Paulista-UNESP, São Paulo, pp. 1-7.

- G. Genette. (1972): Discurso del relato, Barcelona, En: Figuras III.: Lumen.

- García Márquez, Gabriel:

- (2002): Vivir para contarla, Editorial Sudamérica. 1a. ed. Buenos Aires.

- Fantasía y creación artística. (1997): Artículo publicado en Notas de prensa 1980-1984, Editorial Norma. Bogotá, Colombia. Mayo de 1997.

- Loureiro, Ángel G. (1991): Problemas teóricos de la autobiografía, Anthropos: Boletín de información y documentación, ISSN 0211-5611, № Extra 29, 1991 (Ejemplar dedicado a: La autobiografía y sus problemas teóricos. Estudios e investigación documental), pp. 2- 9.

- Martin, Gerald (2009): Gabriel García Márquez, una vida. (Libro), Editorial Random House Mondadori. Barcelona, España.

- Mendoza, Plinio Apuleyo y García Márquez, Gabriel. (2004): El olor de la guayaba. Grupo Editorial Random House Mondadori. Madrid, España.

- Molloy, Sylvia: (1996), La escritura autobiográfica en Hispanoamérica, Acto de presencia, México: El Colegio de México : Fondo de Cultura Económica (FCE).

- Ospina, William. García Márquez y el poder de la poesía. Artículo de la revista Número. www.revistanúmero.com. Edición 52. Marzo - mayo de 2007. Fecha de la visita de la revista web: 20/12/2018, 8:00 PM.

- Paz, Octavio. (1981), La pregunta de Carlos Fuentes, Artículo publicado en In/mediaciones.

Barcelona: Seix Barral, pp. 175 - 179.

- Vargas Llosa,Mario.

- $\quad$ (1996), La verdad de las mentiras, pp. 7 - 18.

- (1971), García Márquez. Historia de un suicidio, Barcelona: Barral. pp. 183 - 184.

\section{WEBIOGRAFÍA}

- Cobo Borda, Juan Gustavo, (2002): Vivir para contarla, de Gabriel García Márquez. El filón del joyero. 31 de diciembre de 2002, Letras Libres, https://www.letraslibres.com/mexico/vivir-contarlagabriel-garcia-marquez. Fecha de visita de la página web: 26/01/2019 - 8:30 PM.

- Jensen, Julio Hans Casado: Vivir para contarla como trabajo mnemónico individual y colectivo, 1/1/2006, Universidad de Copenhague, Literaturas coloniales y postcoloniales, Artículo publicado en:

https://www.researchgate.net/publication/277182067_Vivir_para_contarla_como_trabajo_mnemoni co individual_y colectivo, Fecha de visita de la página web: 20/2/2019, 9: 30 PM.

- López, Justo Fernández, García Márquez Gabriel, Artículo sacado de: Historia de la literatura hispanoamericana, www.hispanoteca.eu, Fecha de la visita de la página web: 01 / 02 / 2019

__ Michell García Garduño, Martha: Ensayo del libro "Vivir para contarla", https.//www.monografías.com/docs/ensayo-del-libro-vivir-para-contarla, 19 de mayo de 2013, Fecha de la visita de la página web, 30 / 01/2019. 